\title{
UTAZÓK, KALMÁROK, SZÉLHÁMOSOK: A HATÁRVIDÉKEK SZEREPE A KERESKEDELEMORIENTÁLT TURISZTIKAI TEVÉKENYSÉGEKBEN
}

\author{
${ }^{1}$ Michalkó Gábor - ${ }^{2}$ Tömöri Mihály - ${ }^{3}$ Ilyés Noémi \\ ${ }^{1}$ Budapesti Corvinus Egyetem, CSFK Földrajztudományi Intézet; gabor.michalko@uni- \\ corvinus.hu \\ ${ }^{2}$ Nyíregyházi Egyetem; tomori.mihaly@nye.hu \\ ${ }^{3}$ Magyar Turisztikai Szövetség; ilyes.noemi@magyarturisztikaiszovetseg.hu
}

DOI: 10.15170/TVT.2022.07.01.01.

\begin{abstract}
Absztrakt
A tanulmány a nemzetközi szakirodalom bázisán a határvidékek gazdaságának kereskedelemorientált turisztikai aspektusait tárja fel. A téma feldolgozására a nem konvencionális turisztikai mobilitás teoretikus keretein belül kerül sor. A munka azokkal a kereskedelmi tevékenységekkel foglalkozik, amelyek összefüggésbe hozhatók a turizmussal, mert egyrészt közvetve vagy közvetlenül szolgálják a turisták áramlását, másrészt a szállítás és/vagy az értékesítés részben vagy egészben a turista szerepében, illetve a turisták számára zajlik. A szerzők jelentős hangsúlyt fektetnek a csempészet jelenségére, amelynek derékhadát a dohány és a drog illegális transzfere adja. A határbiznisz akár a legális, akár az informális, akár az illegális gazdaság keretében zajlik kevés kivételtől eltekintve érinti a kiskereskedelemi kínálatot is. A jelen tanulmányban tárgyalt, a centrumtól távolabbi tevékenységek többségében az állam ellenőrző funkciója kevésbé hatékony, és azokkal kapcsolatosan szerényebb társadalmi kontroll érvényesül.
\end{abstract}

Kulcsszavak: határvidék, turizmus, kereskedelem, vásárlás, bünözés 


\title{
ROLE OF THE BORDERLANDS IN THE TRADE-ORIENTED TOURISM ACTIVITIES
}

\begin{abstract}
This study reveals the trade-oriented tourism aspects of the economy of the border regions, based on international literature. The topic is processed within the theoretical framework of the border regions and non-conventional tourism mobility. The work deals with commercial activities that could be linked to tourism, since they directly or indirectly serve the flow of tourists and the transport and/or sales happen completely or partially in tourist role, or for the tourists. The authors place significant emphasis on the phenomenon of smuggling, which mainly comes from illegal transfer of tobacco and drugs. With few exceptions, border businesses affect retail supply, whether they happen within the legal, informal or illegal frameworks of the economy. In the case of the off-center activities that are being discussed in this study, the control function of the state is less effective and the social control over them is also modest.
\end{abstract}

Keywords: borderland, tourism, trade, shopping, crime

Köszöntés: A szerzők jelen tanulmányukkal köszöntik a 70 éves Aubert Antal professzort, aki iskolateremtő munkássága révén egyrészt utat tört a magyarországi turizmusföldrajz akadémiai elismeréséhez, másrészt kutatásai és tanítványai révén jelentősen elősegítette a diszciplína fejlödését, kiteljesedését. A határmentiség és a turizmus kapcsolatának feltárása Aubert Antal életművének szerves része, több tanulmányában is érinti az országhatárok által elválasztott térségek turisztikai potenciáljának kérdéskörét. 


\section{Bevezetés}

Az emberiség története a határok kijelölésének, védelmének és kiigazításának története (PARKER 2006, GUO 2018). A második világháborút lezáró békerendszer és az ENSZ megalakulása globális szinten is igyekezett stabilitást teremteni az államokat elválasztó határvonalak tekintetében (WEISS 2015). Ugyan több ezer év történelmi paradigmáját nem lehet az egyik napról a másikra megváltoztatni, de az elmúlt évtizedek azt igazolják, lehetőség van a határok funkciójának újraértelmezésére. Ebben a folyamatban a gazdasági érdekek gyakran felülírják a politikait, erősödik a felismerés, hogy a turizmus, a „béke iparága”, a határ menti térségekben is jelentős gazdaságélénkítő potenciállal bír (D’AMORE 1988, LITVIN 1998, FRANCH et al. 2017).

A határok értelmezésével kapcsolatos dichotómia a határok nélküli világ határainak meghúzásában gyökeredzik, vagyis abban, hogy a politikum milyen mértékben engedi meg a határok elválasztó funkciójának oldását (DIENER - HAGEN 2009). Miközben a XX. század utolsó évtizedeinek gazdasági-társadalmi folyamatai a határok korlátozó szerepének fokozatos redukálását generálták, addig a XXI. század első évtizedeiben éppen ellenkező előjelü törekvéseknek lehetünk szemtanúi (PAASI 2019). A világ egyik legnagyobb integrációja, az Európai Unió létrejötte és bővülési folyamata a határok nélküli Európa létrehozásának ideológiája mentén törekszik a határok lebontására (DEDMAN 1996). Az Európai Unió legfontosabb irányelve, az áruk, a szolgáltatások, a tőke és a személyek szabad áramlása a határok lényegi jellemvonásának, a különbözőség fenntartásának szab gátat. A mobilitás szinte korlátlan szabadsága kiválóan megmutatta, hogy a határok mentén észlelhető gazdasági, társadalmi, kulturális, táji stb. különbségek fenntartásában és hasznosításában a turizmus kulcsfontosságú szerepet tölt be (TIMOTHY - SAARINEN 2013). A határvidékeket napjainkban már nem a szomszédos országok haderői, hanem turistái tartják megszállás alatt, fogyasztásuk - a legtöbb esetben - pedig már nem fenyegetést, hanem kézzel fogható hasznot jelent az érintett térségek számára (IRIMIÁS 2014).

A XXI. század első évtizedeiben lezajló nemzetközi események rávilágítottak a határok értelmezésének kettősségében rejlő nehézségekre. Az overtourism és egyes turistaellenes mozgalmak felvetették a határellenőrzés visszaállításának, szigorításának mint az áramlás lassításának lehetséges alternatíváját is (BUTLER 2019, HIGGINS-DESBIOLLES et al. 2019). Az Európát sújtó 2015. évi nemzetközi migrációs válság már egyenesen arra kényszerítette a politikai döntéshozókat, hogy a határaikon átmenetileg felállított müszaki akadályokkal és a fegyveres erők közremüködésével gátolják meg a nagyszámú menekült országukon történő áthaladását vagy az odaérkezését (KOCSIS et al. 2017). A Covid-19 járvány a határok lezárásával, az átlépés szigorú feltételekhez történő kötésével globálisan korlátozta a turisztikai mobilitást (GÖSSLING et al. 2020).

A határok turizmusban betöltött szerepével foglalkozó kutatások számtalan elemét feltárták már a turisztikai mobilitás és a biztonság sajátos szimbiózisának (TIMOTHY - TOSUN 2003, GELBMAN 2008). Ezekből a munkákból jól kirajzolódik a határvidékek azon természete, amely a kívánatos és látszólagos rend, valamint a színfalak mögötti, azonban a társadalmi, gazdasági stabilitást (az egzisztenciát) kínáló rendetlenség dichotómiájából fakad. A határvidékeken az állam kiemelt biztonságot garantál, amely az ott élők érdeke is. Ugyanakkor a különbözőségekből fakadó üzleti lehetőségek kiaknázására létrejött legális kereskedelmi és turisztikai szolgáltatások magukban rejtik az informális és az illegális gazdaság kialakulásának lehetőségét is (TIMOTHY - TEYE 2005, GELBMAN - TIMOTHY 2011, YALÇINHECKMANN - AIVAZISHVILI 2012, GAO et al. 2019). 


\section{A nem konvencionális turisztikai mobilitás a határ menti térségekben}

A határvidékek a nem konvencionális turisztikai mobilitás kitüntetett térszínei. A nem konvencionális turisztikai mobilitás olyan utazási tevékenység, amelynek során egyrészt nem (vagy nem teljeskörüen) kerül sor a tartózkodás regisztrálására, másrészt a fogyasztói magatartás és az azt befolyásoló utazási indítékok a turizmus hagyományos értelmezési tartományának mezsgyéjén vagy azon kívül esnek (KLEMM 2002, NOVELLI 2005, DE CANTIS et al. 2015, RÁTZ et al. 2015, HEUNG-RYEL et al. 2019). A nem konvencionális turisztikai mobilitás a turizmus XXI. századi fejlődésének hozadéka, a légi közlekedés üzleti modellváltása (DOBRUSZKES 2006), a megosztáson alapuló gazdaság előtérbe kerülése (HEO 2016), a munka és a szabadidős aktivitás térszíneinek átfedése (PÉCSEK 2018), a mobilitás korlátozó tényezőinek (a határellenőrzés, vízumkötelezettség) oldódása (BIGO GUILD 2005), a migrációs aktivitás (beleértve a diákmigrációt) intenzitása (RAGHURAM 2013), a második otthonok elterjedése (HALL 2014) és a digitalizáció (JANSSON 2020) megváltoztatta a turizmus természetét. A turisztikai desztinációk tervezéssel, fejlesztéssel, menedzseléssel foglalkozó szakembereinek egyre inkább számolnia kell a rövid tartózkodási idejü látogatók (TOMONORI et al. 1994), a regisztrált szálláshelyeken kívül megszállók (pl. második otthon, szívességi szálláshely) (GALLENT et al. 2016), a VFR turisták (ZÁTORI et al. 2019), a munkájukat egy turisztikai desztinációban végzők (LUNDBERG et al. 2009), az átutazók (TÓTH et al. 2017) és a tényleges utazási motivációjukat álcázók/leplezők (RYAN KINDER 1996) keresletével. A kvázi turisták a nem konvencionális turizmus föszereplői, részben átfedést mutatnak az új turistákkal, akiknek fogyasztói magatartása közelebb áll a turizmus tradicionális értelmezéséhez (BACK - MARJAVAARA 2017). A határvidékek a kvázi turisták tanulmányozásának laboratóriumai.

A határ meneti térségek elsősorban az átutazással, a rokonok és barátok meglátogatásával, a nemzeti emlékezet ápolásával, az egészségügyi, oktatási, vendéglátó-ipari, kiskereskedelmi és javító szolgáltatások igénybevételével, a szerencsejáték-iparral, a prostitúcióval, a pszeudokülkereskedelemmel és a csempészettel összefüggő utazások révén válnak a nem konvencionális turisztikai mobilitás térszíneivé. A határ menti térségekben megvalósuló nem konvencionális turisztikai tevékenységek és az azokat kiszolgáló kínálati elemek a legálisinformális-illegális skála különbözö pontjain helyezkednek el. Ezen piac müködésének sajátossága, hogy egyrészt igyekszik kihasználni a szolgáltatások közötti szinergiákban rejlö lehetőségeket, másrészt az átfedések révén ugyanazon utazás a legális-informális-illegális skála különböző pontjaira helyezheti a látogatót. A téma tárgyalásakor arról sem szabad megfeledkezni, hogy a különböző kiterjedésű szárazföldi határvidékek (kontaktzónák) mellett jelentős szerepük van a vizek menti határvidékeknek is (BOWERS - KOH 2019). Ebböl a szempontból vizsgálhatók a tenger- vagy óceánparti miniállamokat, illetve városállamokat övező térségek, valamint a hajózási útvonalakhoz kapcsolódó kikötők, határellenőrzési pontok, vámterületek.

\section{A turizmus (határ)gazdaságtana}

A határvidékek gazdaságának legfontosabb mozgatórugója a különbözőség, amelyet a kereskedelem és a turizmus külön-külön, illetve egymással szimbiózisban is hasznosít. A különbözőség természeti és társadalmi okokra és azok egymásra gyakorolt hatására egyaránt visszavezethető (RUMLEY - MINGHI 2014). A különbözőségek, így a hasznosításuk is, leginkább azokon a határvidékeken észlelhető, amelyek benépesedettek és évszázados gazdasági-társadalmi fejlődésen mentek keresztül. A különbözőség (a közeli egzotikum) átélése önmagában képes a külföldre utazás érzetét, így az útra kelést kiváltani (SEDDIGHI THEOCHAROUS 2002, COHEN - AVIELI 2004). 
A kereskedelem a határ menti különbözöségek hasznosításának egyik letéteményese. A kereskedelem infrastruktúráját a raktárbázisok, a konténertárolók, a vámterületek (ideértve a vámszabadterületeket, a vámszabad raktárakat és a tranzit területeket is) képezik. A határ menti kereskedelem döntő mértékben a teherforgalom kiszolgálását jelenti, amelynek bonyolítása történhet közúton, vasúton és vízi úton is. Különösen kiterjedt infrastruktúrára van szükség, amikor a határok a szállítási útvonalon szállítási mód váltást is jelentenek. A határ menti kereskedelmi zónák munkaerőigényesek, a raktározás, a vámolás, a feldolgozás, a csomagolás, az infrastruktúra üzemeltetése, a biztonság garantálása stb. jelentős számú munkavállaló ellátását igényli. A szükséges munkaerő szállításában (tömegközlekedés), élelmezésében (vendéglátóipar, kiskereskedelem), fogyasztási cikkekel való ellátásában (üzletek, gyógyszertárak, üzemanyagtöltő-állomások), éjszakai tartózkodásuk biztosításában (szállodák, apartmanok, motelek) a turizmust is kiszolgáló infra- és szuprastruktúra vesz részt (CHEN et al. 2016).

A határ menti kiskereskedelem alapvetően a térség lakosságának és az ott dolgozó munkavállalók ellátását biztosítja, azonban fejlődésében meghatározó szerepet játszik az áruszállítást végzők, az átutazók és a turisták igényeinek kielégítése. A határ mentén realizálódó, konvencionális és nem konvencionális turizmuson belül különleges helyet foglal el a bevásárlóturizmus, amely alapvetően a kiskereskedelmi egységekben történő beszerzés indítékára épül (TIMOTHY 2005). A határ menti bevásárlóturizmus legfontosabb sajátossága, hogy rövid időtartamú, jobbára gépkocsival megvalósuló vásárlás, amelynek színhelyei a jó megközelítési és parkolási lehetőségeket kínáló hiper- és szupermarketek, outletek és a piacok (például használt autó, ruházat). A bevásárlóturizmus a határvidékek árukínálatában meglévő különbözőségekre épül, működését a libikóka-modell írja le (MICHALKÓ et al. 2014). A bevásárlóturizmus lényegi sajátossága, hogy a vásárlás szükséglete más turisztikai motivációkkal is párosulhat (BARCZA 2020).

A határvidékek alapvetően az adott állam lenyomatai, még a változatos természeti, társadalmigazdasági adottságokkal rendelkező országokban is a szélesen értelmezett kultúra esszenciáját tükrözik. A határvidékek az első benyomás megszerzésének, gyakran a kulturális sokk átélésének színterei, amelyet a fizikai határok és a határellenőrzés procedúrája még inkább megerősít (FURNHAM 1984, BYRNE 2001). Ott, ahol a határok átlépése az infrastruktúra használatában is lényeges változással párosul, a biztonság megőrzése érdekében sokkal körültekintőbben, a helyi jogszabályokhoz maximálisan alkalmazkodva kell tovább haladni. Egy „Balra tarts!” (jobbkormányos) közlekedési rendszerü térségből egy „Jobbra tarts!” (balkormányos) térségbe történő belépés vagy az eltérő közlekedési (pl. autópálya-használati) szabályok betartása a balesetek, az ápolási és javítási költségek, valamint a tetemes bírságok elkerülése miatt is elsődleges fontosságú. A határvidékeken realizálódó bevételek között így a gépjármüre kötendő kötelező felelősségbiztosítás, zöldkártya, úthasználati díj, az elöírt gépkocsi tartozékok (pl. egy alpesi országban hólánc), az utasoknak biztosítás, vízum stb. is elöfordulhatnak.

\section{A határ menti informális kiskereskedelem általános jellemzői}

Az informális határ menti kereskedelem az informális gazdaság tárgykörébe tartozó tevékenység. Az informális gazdaság olyan jövedelemgeneráló tevékenységek összessége, amelyek nem állnak az állami/társadalmi intézményrendszer kontrollja alatt (CASTELLS PORTES 1989, TIMOTHY 1997, PORTES - HALLER 2010). Az informális gazdaság önmagában nem értelmezhető, csak a formális, azaz szabályozott, ellenőrzött jövedelemtermelő tevékenységekhez kapcsolódó viszonyrendszerében érhető meg (SASSEN 1994). Az informális gazdaság tehát az állam számára láthatatlan, nem regisztrált tevékenységek összességét takarja, melyek elsősorban adóelkerülést vagy más haszonszerzési célt szolgálnak és amelyek máskülönben legálisak lennének. Természetesen a formális és informális 
tevékenységek között sokszor nem lehet éles különbséget tenni, hiszen ezek a folyamatok gyakran átfedik egymást, ezért sokkal szerencsésebb inkább egy formális-informális kontinuumról beszélni.

A határ menti kiskereskedelem az arbitrázs egyik formája, melynek résztvevői a piacok (országok) között tapasztalható eltérő árszintekből igyekeznek hasznot húzni azáltal, hogy az egyik piacon alacsonyabb áron beszerzett terméket egy magasabb árakkal jellemezhető piacon értékesítik (WILLIAMS - BALÁŽ 2002). A határon átívelő fogyasztási tevékenység mindaddig legális tevékenységnek tekinthető, ameddig a megvásárolt termékek az érintett országok jogrendszereinek értelmében legálisnak minősülnek, illetve az árucikkek beszerzése, szállítása és értékesítse formális módokon történik. A gyakorlati tapasztalatok azonban azt mutatják, hogy a határ menti kereskedelem egy tekintélyes része nem felel meg a fenti kritériumoknak, azaz az informális, illetve illegális gazdasági tevékenységek közé sorolható.

Természetesen a legtöbb esetben a határ menti kereskedelem formális, informális, illetve illegális aspektusai sem különíthetők el egymástól élesen. Az informális kereskedelem egyik gyakran hangoztatott kritériuma például, hogy az abban résztvevők elkerülik a vámok és más adóterhek megfizetését (AFRIKA - AJUMBO, 2012), ugyanakkor egyáltalán nem ritka eset, hogy a kereskedők nem teljesen, hanem csak részben kerülik meg a kötelezettségeket, hiszen előfordulhat, hogy egyes adófajtákat (pl. helyi adó) befizetnek, másokat (pl. társadalombiztosítási járulékok) viszont nem. Az sem példa nélküli továbbá, hogy a formális szektorban müködő vállalkozások a nagyobb profit elérése érdekében illegális csatornákon (pl. csempészet) keresztül is vásárolnak termékeket (CANTENS et al. 2015).

A határ menti kiskereskedelem gyakorlatilag a világ valamennyi részén tetten érhető jelenség, de a társadalmi, gazdasági, politikai körülmények a fejlődő, illetve a volt szocialista országok esetében különösen kedvező feltételeket teremtettek e tevékenység számára (WILLIAMS BALÁŽ 2002). A határ menti kiskereskedelem ezekben az országokban a jövedelemszerzés, illetve -kiegészítés fontos forrását jelenti, hiszen a formális munkaerőpiacon a foglalkoztatási és kereseti lehetőségek korlátozottak. A határ menti kereskedelemben a legtöbb esetben egyaránt jelen vannak az éppen aktuális profitlehetőségeket keresők (opportunisták), valamint a napi túlélésért küzdők, de természetesen a motivációk térben és időben is nagy változékonyságot mutatnak. A határ menti kereskedelem azonban nemcsak egy átmenti túlélési stratégiaként értékelhetö, hanem a gazdasági tevékenységek alternatív terepeként is (SMITH 2000). Tapasztalatok szerint a határ menti kereskedelemben sokszor nem a legszegényebbek a legaktívabbak, hanem azok, akik jobb anyagi helyzetükböl és kiterjedtebb kapcsolati hálójukból fakadóan hatékonyabban aknázzák ki e tevékenységben rejlő lehetőségeket (XHENETI et al. 2013, NAGY 201).

A határ menti kereskedelem kockázatos vállalkozás, mert a kereskedők részben vagy teljes mértékben illegálisan dolgoznak és a határ túloldalán érvényben lévő szabályok, intézményi keretek sokszor jórészt ismeretlenek számukra (SMALLBONE - WELTER 2012). Ráadásul a kereskedők számára a megbízhatatlan üzleti partnerek, a szervezett bünözői csoportok, a folyamatosan változó jogszabályi környezet, valamint a bünüldöző szervek is potenciális veszélyforrást jelentenek. A kockázatvállalás a vállalkozói döntés folyamatában is jelen van, hiszen a kereskedőknek folyamatosan mérlegelniük kell, hogy mit, mikor, milyen mennyiségben és milyen határszakaszokon érdemes szállítani (NGO - HUNG 2019). A határ menti kereskedelemben sikeressége szempontjából ezért kulcsszerepe van a bizalomnak, illetve a családi, etnikai, baráti kapcsolatok formájában felhalmozott társadalmi tőkének (kapcsolati hálónak), melyek hozzájárulhatnak a kockázatok mérsékléséhez. Szintén kockázatcsökkentő tényezőként értékelhető a határörökkel és vámtisztekkel kialakított sajátos kapcsolatrendszer, amely a megvesztegetés intézményrendszerében (WILLIAMS - BALÁŽ 2005) nyilvánul meg. 
Az informális határ menti kiskereskedelem és a politikai, hatalmi tényezők folyamatosan kölcsönhatásban állnak egymással, hiszen az árucserében résztvevők az állam által megalkotott és érvényesíteni kívánt törvények, illetve szabályok kijátszására törekednek (SIK 2012). A kelet-európai volt szocialista országokban a rendszerváltozásokat megelőzően kialakult sajátos, informális nemeztközi kereskedelmi rendszer sem az ügyeskedők leleményessége, hanem az állam elnéző magatartása (szemet hunyása) miatt maradhatott fenn (WESSELY 2000). Az államnak pedig racionális érdeke füződött az informális kereskedelem fenntartásához, ugyanis ez a tevékenység hozzájárult a regnáló hatalom stabilitásához amennyiben a politikai reformtörekvések helyett az anyagi szükségletek kielégítése felé terelte az embereket (HOLEŠOVSKÝ 1965). A status quo konzerválásából és a politikai hatalom megőrzéséből fakadó előnyök tehát nem feltétlenül sarkallják arra az államokat, hogy fellépjenek az informális/illegális tevékenységekkel szemben.

\section{Dohánytermékek illegális kereskedelme}

A cigaretta az illegális kereskedelem egyik legnépszerübb árucikke, tekintettel arra, hogy a legtöbb országban magas adókkal terhelik, miközben könnyü szállíthatósága, illetve a társadalom toleráló hozzáállása miatt csempészete csekély kockázattal jár, és számottevő profitot ígér (ALLEN 2012). A dohánytermékek illegális kereskedelme világszerte elterjedt jelenség és bár pontos nagyságrendje nem ismert, egyes becslések szerint a világon elfogyasztott cigaretták és dohánytermékek valamivel több mint 10\%-a illegális forrásból származik (JOOSSENS - RAW 2012).

A cigaretták és dohánytermékek alapvetően legális árucikknek számítanak, így akkor válhatnak illegális termékké, ha nem fizetik meg utánuk a fogyasztási adókat, illetve vámokat, valamint, ha az utazók a személyes fogyasztásukat meghaladó mennyiséggel próbálják meg a határt átlépni (FATF 2012). Az adóelkerülés révén a fogyasztók a legális csatornákhoz képest olcsóbban juthatnak dohánytermékekhez (pénzt spórolhatnak), a kereskedők pedig profitra tehetnek szert azáltal, hogy részben vagy teljesen elkerülik az adók megfizetését (VON LAMPE 2011).

A dohánytermékek illegális kereskedelmének három nagy fázisa különböztethető meg: beszerzés, szállítás, elosztás (VON LAMPE 2011). Az illegális kereskedelembe kerülő termékek beszerzése alapvetően négyféle forrásból valósulhat meg (VON LAMPE et al. 2014): csempészet, nagy léptékü csempészet, illegális „tiszták” és hamisítás. A csempészet lényege, hogy a cigarettát egy olyan országban (tagállamban) vásárolják meg, ahol alacsony adók terhelik a terméket, majd egy olyan országban (tagállamban) értékesítik, ahol az adók mértéke magasabb. Ebben az esetben a származási országban megfizetik az adókat, a célországban azonban nem. Ez a módszer tehát a határ két oldalán megfigyelhető eltérő adószintek okozta árkülönbségeket aknázza ki. A nagy léptékü csempészet jellemzője, hogy az adókat és egyéb terheket sem a származási, sem a célországban nem fizetik meg. Ennek tipikus esete, amikor az exportra szánt (éppen ezért a származási országban nem adóztatott) cigarettákat akár a hazai, akár a külföldi feketepiacokon értékesítik. Az illegális „tiszta” termékeket rendszerint legálisan állítják elő, azonban olyan országokban, államokban forgalmazzák őket, ahol ez nem engedélyezett. Természetesen az sem zárható ki, hogy egy egyedi márkanévvel rendelkező terméket eleve a feketepiacon való értékesítés szándékával állítanak elö. Végül, de nem utolsósorban a beszerzés forrása lehet a termékhamisítás is, melynek során olyan cigarettákat állítanak elö, amelyeken a márkajelzést a védjegyek tulajdonosainak engedélye nélkül tüntetik fel.

Az illegális kereskedelem következő fázisa a szállítás, ami a termékek határokon való rejtett átjuttatását jelenti (VON LAMPE 2011). A csempészet módszerei elsősorban nem a beszerzési forrásoktól, hanem a szállítmányok nagyságától függenek. A nagy tételeket (tipikusan 1 millió 
szál felett) általában legális árucikkek mögé, vagy közé rejtik és szállításukat megpróbálják legális kereskedelmi tevékenységnek álcázni. A kisebb tételeket nem az áru- hanem a személyforgalom részeként csempészik át a határokon, de természetesen a zöldhatáron való átkelési próbálkozások is elterjedtek. Gyakori módszer, hogy a cigarettát a gépkocsik, vagy kisteherautók külön erre a célra kialakított rejtett rekeszeiben, vagy átalakított üzemanyagtartályaiban próbálják meg elrejteni, de a postai csomagküldés sem ismeretlen jelenség.

Az utolsó fázisban az illegális forrásból származó cigaretták elosztására, illetve értékesítésére kerül sor, amire szintén többféle módszer létezik (VON LAMPE 2011). Az értékesítés történhet nyilvános, félig nyilvános és magánterekben. A nyilvános tereken (pl. utcák, bolhapiacok) a cigaretták utcai árusoktól, kereskedőktől szerezhetők be, akik gyakran a járókelőket leszólítva kínálják portékájukat. A félig nyilvános terekben (pl. bárok, kioszkok) az illegális cigarettákat a pult alól lehet megvásárolni, mint a legális termékek alternatíváit. Bizonyos esetekben a kereskedők a fogyasztókat megtévesztve legálisként árult, hamis vagy lopott termékeket is értékesíthetnek a vásárlók számára. Végül, de nem utolsósorban az illegális forrásból származó cigaretták adásvétele a családi, illetve baráti kapcsolatok révén a magánterekben is megjelenhet.

A dohánytermékek illegális kereskedelmében az országok, illetve tagállamok között megfigyelhető jelentős árkülönbségek mellett egyéb tényezők is szerepet játszhatnak. Ezek között megemlíthető a kormányzatok gyengesége, a korrupció, az elosztási csatornák elérhetősége (NATIONAL RESEARCH COUNCIL 2015), a bünözői hálózatok szervezettsége, a lebukás esélye, illetve a büntetési tételek nagysága (JOOSSENS et al. 2014). A dohánytermékek illegális kereskedelmében a dohánygyártó cégek is érintettek lehetnek (NATIONAL RESEARCH COUNCIL 2015), hiszen e vállalatoknak érdekében állhat, hogy saját, legálisan előállított termékeiket olyan piacokra csempésszék, ahol azokat törvényesen nem forgalmazhatják. Ennek révén termékeiket új piacokra is bevezethetik és növelhetik piaci részesedésüket.

\section{Drogcsempészet}

A kábítószerek illegális kereskedelme összetett jelenség, amely magában foglalja a törvények által tiltott anyagok termelését, gyártását, forgalmazását és értékesítését. A drogkereskedelem jellege országok és termékek szerint igen nagy különbségeket mutat. A heroin és kokain esetében a termelést erős földrajzi koncentráció jellemzi, ami nagy távolságokat átfogó ellátási láncokkal párosul. Ezzel szemben a marihuána termelése jóval decentralizáltabb, szinte valamennyi országban foglalkoznak az előállításával, ezért az ellátási láncok is rövidebbek (REUTER 2014).

A gyenge, korrupt kormányokkal rendelkező fejlődő országokban (pl. Mexikó, Kolumbia, Afganisztán) gyakran kiterjedt nemzetközi kapcsolatokkal rendelkező bünügyi szervezetek, illetve drogkartellek szervezik és irányítják a drogkereskedelmet. A drogkartellek felépítése hierarchikus, ugyanakkor a kábítószer-kereskedelemmel foglalkozó bünszervezetek sokszor decentralizált felépítést követnek és müködésük laza társadalmi hálózatokon keresztül valósul meg. E hálózatokon belül gyakran egy-egy részfeladatra (pl. beszerzés, szállítás, export, elosztás, nagy- és kiskereskedelem, pénzmosás) szakosodott csoportot hoznak létre, amelyek a közvetítőkön keresztül kerülnek egymással kapcsolatba, ezzel minimalizálva annak lehetőségét, hogy a bünüldöző szervek felderíthessék a bünszervezetek vezetőinek személyét (KENNEY 2007).

Az ellátási láncok összetettek, melyeken belül meg kell különböztetni a szervezőket (akik tőkét fektetnek be és alkalmazottakkal rendelkeznek), a saját hasznukra dolgozó futárokat/csempészeket, valamint azokat a futárokat (mules), akik megbízásokat teljesítenek. $\mathrm{Az}$ önállóan dolgozó csempészeket (self-employed couriers) alapvetően a profitszerzés 
lehetősége motiválja és rendszerint szabad elhatározásuk alapján vesznek részt ebben a tevékenyégben. Ezzel szemben a megbízásokat teljesítő (másoknak dolgozó) futárok az anyagi haszonszerzés mellett gyakran kiszolgáltatottság, kényszerítés, illetve fizikai erőszak alkalmazása miatt válnak a rendszer részévé (FLEETWOOD et al. 2015).

Az illegális kábítószerkereskedelmi útvonalak kialakulásában a ráfordítások (költségek, kockázatok), illetve az elérhető profitok nagysága, valamint a földrajzi és társadalmi, kulturális tényezők játszanak szerepet. A drogcsempészek olyan útvonalakat választanak, amelyek a legkisebb költség és kockázat mellett a legnagyobb profitot biztosítják. A drogcsempészet szempontjából kedvezőek azok a térségek, ahol alacsony a népsürüség és sürü erdők borítják a felszínt, hiszen ez lehetővé teszi, hogy a csempészek rejtve maradjanak. Ugyanakkor a jó minőségü úthálózat is fontos, mert csökkenti a szállítási időt (MEDEL et al. 2015). A bünüldöző szervek müködési hatékonyságának javulása csökkenti kábítószer-kereskedelem intenzitását, mivel a kereskedőknek növekvő kockázatokkal kell szembesülniük. A termelő és fogyasztó országok földrajzi közelsége elősegítheti azt, hogy egy állam a kábítószer-kereskedelem tranzitországává váljon, hiszen a szállítási költségek és kockázatok minimalizálása a szállítási távolságok csökkentését követeli meg. A földrajzi közelség minden bizonnyal fontos szerepet játszott abban, hogy az Egyesült Államok és Nyugat-Európa felvevőpiacai felé tartó útvonalak Mexikón, illetve a Balkánon keresztül vezetnek. A földrajzi közelség mellett azonban a szociokulturális faktorok hasonlósága is lényeges tényező, hiszen a migrációs kapcsolatok, a nyelvi és kulturális hasonlóság más termékekhez hasonlóan, a kábítószerek kereskedelmét is elösegítheti (REUTER 2014, GIOMMONI et al. 2017).

A különböző kábítószereknek jól beazonosítható kereskedelmi rendszerei alakultak ki. A heroint elsősorban szárazföldi útvonalokon szállítják, gyakran legális teherszállítmányokkal együtt, a kokain esetében ugyanakkor inkább a tengeri szállítás dominál, ahol esetenként nem kereskedelmi célú hajókat is alkalmaznak (pl. jachtok, speciális csónakok). A szintetikus drogok esetében a légi szállítás szerepe meghatározó, amely során a drogfutárok saját testükben vagy csomagjaikba rejtve próbálják a kábítószereket célba juttatni (UNODC 2020).

A kábítószerek kereskedelmével foglalkozó bünszervezetek rendkívül rugalmasak, képesek gyorsan alkalmazkodni a változó társadalmi, gazdasági, politikai és piaci körülményekhez. Éppen ezért a drogokkal szemben történő keményebb fellépés, illetve a szigorúbb határellenörzés nem feltétlenül csökkenti a kábítószerkereskedelem nagyságát, mivel az ún. léggömb hatás értelmében, ha lezárnak egy drogszállító útvonalat, akkor hamarosan kialakul egy másik, ahol a csempészek új módszereket (pl. álcázási technikák) fognak alkalmazni (BAGLEY 2013, TAYLOR et al. 2013, , GIOMMONI et al. 2017).

\section{Köszönetnyilvánítás}

A jelen tanulmányban közreadott ismeretek feltárásához az OTKA K134877 projekt nyújtott támogatást.

\section{Irodalomjegyzék}

AFRIKA, J. G. - AJUMBO, G. (2012): Informal cross border trade in Africa: Implications and policy recommendations. Africa Economic Brief 3(10): pp. 1-13.

ALLEN, E. (2012): The illicit trade in tobacco products and how to tackle it. World Customs Journal 6(2): pp. 121-130. 
BACK, A. - MARJAVAARA, R. (2017): Mapping an invisible population: the uneven geography of second-home tourism. Tourism Geographies 19(4): pp. 595-611. DOI: https://doi.org/10.1080/14616688.2017.1331260

BARCZA, A. (2020): Sopron örökségturisztikai értékeinek vizsgálata a turisták térhasználata alapján. Turisztikai és Vidékfejlesztési Tanulmányok 5(4): pp. 56-71. DOI: https://doi.org/10.15170/TVT.2020.05.04.04

BAGLEY, B. (2013): The evolution of drug trafficking and organized crime in Latin America. Sociología, problemas e práticas 71: pp. 99-123.

BIGO, D. - GUILD, E. (eds.) (2005): Controlling Frontiers-Free Movement into and within Europe. Ashgate, Burlington.

BOWERS, I. - KOH, S. (eds.) (2019): Grey and White Hulls - An International Analysis of the Navy-Coastguard Nexus. Palgrave-Macmillan, Singapore.

BUTLER, R. (2019): Overtourism and the Tourism Area Life Cycle. In: Dodds, R. - Butler, R (eds.): Overtourism:Issues, realities and solutions. De Gruyter Studies in Tourism 1. De Gruyter, Berlin. pp. 76-94.

BYRNE, D. (2001): On Passports and Border Controls. Annals of Tourism Research 28(2): pp. 399-416. DOI: https://doi.org/10.1016/S0160-7383(00)00050-5

CANTENS, T. - IRELAND, R. - RABALLAND, G. (2015): Introduction: borders, informality, international trade and customs. Journal of Borderlands Studies 30(3): pp. 365380. DOI: https://doi.org/10.1080/08865655.2015.1068207

CASTELLS, M. - PORTES, A. (1989): World underneath: The origins, dynamics, and effects of the informal economy. In: Portes, A. -Castells, M. -Benton, L. A. (eds.): The informal economy: Studies in advanced and less developed countries. Johns Hopkins University Press, Baltimore. pp. 11-37.

CHEN, S. - JEEVAN, J. - CAHOON, S. (2016): Malaysian Container Seaport-Hinterland Connectivity: Status, Challenges and Strategies. The Asian Journal of Shipping and Logistics 32(3): pp. 127-137. DOI: https://doi.org/10.1016/j.ajsl.2016.09.001

COHEN, E. - AVIELI, N. (2004): Food in Tourism Attraction and Impediment. Annals of Tourism Research 31(4): pp. 755-778. DOI: https://doi.org/10.1016/j.annals.2004.02.003

D'AMORE, L. (1988): Tourism - The World's Peace Industry. Journal of Travel Research 27(1): pp. 35-40. DOI: https://doi.org/10.1177/004728758802700107

DE CANTIS, S. - PARROCO, A. - FERRANTE, M. - VACCINA, F. (2015): Unobserved tourism. Annals of Tourism Research 50(January): pp. 1-18. DOI: https://doi.org/10.1016/j.annals.2014.10.002

DEDMAN, M. (1996): The Origins and Development of the European Union 1945-95. Routledge, London. DOI: https://doi.org/10.4324/9780203131817

DIENER, A. - HAGEN, J. (2009): Theorizing Borders in a Borderless World: Globalization, Territory and Identity. Geography Compass 3(3): pp. 1196-1216. DOI: https://doi.org/10.1111/j.1749-8198.2009.00230.x

DOBRUSZKES, F. (2006): An analysis of European low-cost airlines and their networks. Journal of Transport Geography 14(4): pp. 249-264. DOI: https://doi.org/10.1016/j.jtrangeo.2005.08.005 
FATF (2012): Illicit Tobacco Trade. Financial Action Task Force/Organisation for Economic Cooperation and Development, Paris.

FLEETWOOD, J. - RADCLIFFE, P. - STEVENS, A. (2015): Shorter sentences for drug mules: The early impact of the sentencing guidelines in England and Wales. Drugs: Education, Prevention and Policy 22(5): pp. 428-436. DOI: https://doi.org/10.3109/09687637.2015.1011607

FRANCH, M. - IRIMIÁS, A. - BUFFA, F. (2017): Place identity and war heritage: managerial challenges in tourism development in Trentino and Alto Adige/Südtirol. Place Branding and Public Diplomacy 13(2): pp. 119-135. DOI: https://doi.org/10.1057/s41254-016-0019-5

FURNHAM, A. (1984): Tourism and Culture Shock. Annals of Tourism Research 11: pp. 4157. DOI: https://doi.org/10.1016/0160-7383(84)90095-1

GALLENT, N. - MACE, A. - TEWDWR-JONES, M. (2016): Second homes: European perspectives and UK policies. Routledge, Boca Raton.

GAO, J. - RYAN, C. - CAVE, J. - ZHANG, C. (2019): Tourism border-making: A political economy of China's border tourism. Annals of Tourism Research 76(May): pp. 1-13. DOI: https://doi.org/10.1016/j.annals.2019.02.010

GELBMAN, A. (2008): Border Tourism in Israel: Conflict, Peace, Fear and Hope. Tourism Geographies 10(2): pp. 193-213. DOI: https://doi.org/10.1080/14616680802000022

GELBMAN, A. - TIMOTHY, D. (2011): Border Complexity, Tourism and International Exclaves - A Case Study. Annals of Tourism Research 38(1): pp. 110-131. DOI: https://doi.org/10.1016/j.annals.2010.06.002

GIOMMONI, L. - AZIANI, A. - BERLUSCONI, G. (2017): How do illicit drugs move across countries? A network analysis of the heroin supply to Europe. Journal of Drug Issues 47(2): pp. 217-240. DOI: https://doi.org/10.1177/0022042616682426

GÖSSLING, S. - SCOTT, D. - HALL, M. (2020): Pandemics, tourism and global change: a rapid assessment of COVID-19. Journal of Sustainable Tourism 29(1): pp. 120.https://doi.org/10.1080/09669582.2020.1758708

GUO, R. (2018): Cross-Border Resource Management. Elsevier, Amsterdam.

HALL, M. (2014): Second Home Tourism: An International Review. Tourism Review International 18(3): pp. 115-135. DOI:10.3727/154427214X14101901317039

HEO, C. (2016): Sharing economy and prospects in tourism research. Annals of Tourism Research 58(January): pp. 166-170. DOI:10.1016/j.annals.2016.02.002

HEUNG-RYEL, K. - CHANGHYO, Y. - YOONJEUNG, J. (2019): Relationships among overseas travel, domestic travel, and day trips for latent tourists using longitudinal data. Tourism Management 72(June): pp. 159-169. DOI: https://doi.org/10.1016/j.tourman.2018.11.018

HIGGINS-DESBIOLLES, F. - CARNICELLI, S. - KROLIKOWSKI, C. - WIJESINGHE, G. - BOLUK, K. (2019): Degrowing tourism: rethinking tourism. Journal of Sustainable Tourism 27(12): pp. 1926-1944. DOI: https://doi.org/10.1080/09669582.2019.1601732

HOLEŠOVSKÝ, V. (1965): Personal consumption in Czechoslovakia, Hungary, and Poland, 1950-1960: a comparison. Slavic Review 24(4): pp. 622-635. DOI:10.2307/2492894

IRIMIÁS, A. (2014): The Great War heritage site management in Trentino, northern Italy. Journal of Heritage Tourism 9(4): pp. 317-331. DOI: https://doi.org/10.1080/1743873X.2014.908886 
JANSSON, A. (2020): The transmedia tourist: A theory of how digitalization reinforces the dedifferentiation of tourism and social life. Tourist Studies 20(4): pp. 391-408. DOI: https://doi.org/10.1177/1468797620937905

JOOSSENS, L. - RAW, M. (2012): From cigarette smuggling to illicit tobacco trade. Tobacco Control 21(2): pp. 230-234. DOI:10.1136/tobaccocontrol-2011-050205

JOOSSENS, L. - LUGO, A. - GILMORE, A. B. - CLANCY, L. - GALLUS, S. (2014): Illicit cigarettes and hand-rolled tobacco in 18 European countries: a cross-sectional survey. Tobacco control 23(1): pp. 17-23. DOI: http://dx.doi.org/10.1136/tobaccocontrol-2012-050644

KENNEY, M. (2007): The architecture of drug trafficking: network forms of organisation in the Colombian cocaine trade. Global crime 8(3): pp. 233-259. DOI: https://doi.org/10.1080/17440570701507794

KLEMM, M. (2002): Tourism and Ethnic Minorities in Bradford: The Invisible Segment. Journal of Travel Research 41(August): pp. 85-91. DOI: https://doi.org/10.1177/004728750204100112

KOCSIS, K. - MOLNÁR SANSUM, J. - MICHALKÓ, G. - BOTTLIK, ZS. - SZABÓ, B. BALIZS, D. - VARGA, GY. (2017): International migration into Europe - an old-new challenge from the Afro-Asian neighbourhood. Eurolimes 23-24: pp. 167-190.

LITVIN, S. (1998): Tourism - The World's Peace Industry? Journal of Travel Research 37(1): pp. 63-66. DOI: https://doi.org/10.1177/004728759803700108

LUNDBERG, C. - GUDMUNDSON, A. - ANDRESSON, T. (2009): Herzberg's Two-Factor Theory of work motivation tested empirically on seasonal workers in hospitality and tourism. Tourism Management 30(6): pp. 890-899. DOI: https://doi.org/10.1016/j.tourman.2008.12.003

MEDEL, M. - LU, Y. - CHOW, E. (2015): Mexico's drug networks: Modeling the smuggling routes towards the United States. Applied Geography 60: pp. 240-247. DOI: https://doi.org/10.1016/j.apgeog.2014.10.018

MICHALKÓ, G. - RÁTZ, T. - HINEK, M. - TÖMÖRI M. (2014): Shopping tourism in Hungary during the period of the economic crisis. Tourism Economics 20(6): pp. 1319-1336. DOI: https://doi.org/10.5367/te.2014.0387

NAGY, E. (2017): New consumption spaces and cross-border mobilities. In: Hall, D. R. (ed.): Tourism and geopolitics: issues and concepts from Central and Eastern Europe. CABI, New York. pp. 142-157. DOI:10.1079/9781780647616.0142

NATIONAL RESEARCH COUNCIL (2015): Understanding the U.S. Illicit Tobacco Market: Characteristics, Policy Context, and Lessons from International Experiences. The National Academies Press, Washington, DC.

NGO, T. W. - HUNG, E. P. (2019): The Political Economy of Border Checkpoints in Shadow Exchanges. Journal of Contemporary Asia 49(2): pp. 178-192. DOI: https://doi.org/10.1080/00472336.2018.1555273

NOVELLI, M. (ed): 2005 Niche tourism. Butterworth-Heinemann, Oxford.

PAASI, A. (2019): Borderless worlds and beyond: Challenging the state-centric cartographies. In: Paasi, A. - Prokkola, E. - Saarinen, J. - Zimmerbauer, K. (eds.): Borderless Worlds for Whom? Ethics, Moralities and Mobilities. Routledge, London. pp. 21-36.

PARKER, B. (2006): Toward an Understanding of Borderland Processes. American Antiquity 71(1): pp. 77-100. DOI: https://doi.org/10.2307/40035322 
PÉCSEK, B. (2018): Working on holiday: the theory and practice of workcation. Balkans Journal of Emerging Trends in Social Sciences 1(1): pp. 1-13. DOI: 10.31410/Balkans.JETSS.2018.1.1.1-13

PORTES, A. - HALLER, W. (2010): The Informal Economy. In: Smelser, N. J. - Swedberg, R. (eds.): The handbook of economic sociology. Princeton University Press, Princeton. pp. 403426.

RAGHURAM, P. (2013): Theorising the Spaces of Student Migration. Population, Space and Place 19(2): pp. 138-154. DOI: https://doi.org/10.1002/psp.1747

RÁTZ, T. - KUNDI, V. - MICHALKÓ, G. (2015): The hidden dimensions of cultural consumption within the framework of tourism mobility. In: Sonnenburg, S. - Wee, D. (eds.): Touring Consumption. Springer, Wiesbaden. pp. 285-302. DOI:10.1007/978-3-658-100193_13

REUTER, P. H. (2014): The mobility of drug trafficking. In: Collins, J. (ed.): Ending the drug wars. The London School of Economics and Political Science, London. pp. 33-40.

RUMLEY, D. - MINGHI, J. (eds.) (2014): The Geography of Border Landscapes. Routledge, London.

RYAN, C. - KINDER, R. (1996): Sex, tourism and sex tourism: fulfilling similar needs? Tourism Management 17(7): pp. 507-518. DOI: https://doi.org/10.1016/S02615177(96)00068-4

SASSEN, S. (1994): The informal economy: Between new developments and old regulations. Yale Law Journal 103(8): pp. 2289-2304. DOI: https://doi.org/10.2307/797048

SEDDIGHI, H. - THEOCHAROUS, A. (2002): A model of tourism destination choice: a theoretical and empirical analysis. Tourism Management 23(5): pp. 475-487. DOI: https://doi.org/10.1016/S0261-5177(02)00012-2

SIK, E. (2012): Trust, Network Capital, and Informality - Cross-Border Entrepreneurship in the First Two Decades of Post-Communism. Review of Sociology 4: pp. 53-72.

SMALLBONE, D. - WELTER, F. (2012): Cross-border entrepreneurship. Entrepreneurship \& Regional Development 24(3-4): pp. 95-104. https://doi.org/10.1080/08985626.2012.670907

SMITH, A. (2000): Employment restructuring and household survival in 'postcommunist transition': rethinking economic practices in Eastern Europe. Environment and Planning A 32: pp. 1759-1780. DOI: https://doi.org/10.1068/a32101

TAYLOR, J. S. - JASPARRO, C. - MATTSON, K. (2013): Geographers and drugs: A survey of the literature. Geographical Review 103(3): pp. 415-430. DOI: https://doi.org/10.1111/j.1931-0846.2013.00007.x

TIMOTHY, D. - SAARINEN, J. (2013): Cross-border Cooperation and Tourism in Europe. In: Costa, C. - Panyik, E. - Buhalis, D. (eds.): Trends in European Tourism Planning and Organisation. (Aspects of Tourism, 60) Channel View Publications, Bristol. pp. 64-75.

TIMOTHY, D. - TEYE, V. (2005): Informal sector business travellers in the developing world: a borderlands perspective. Journal of Tourism Studies 16(1): pp. 82-92. DOI: $10.21832 / 9781845414122-009$

TIMOTHY, D. - TOSUN, C. (2003): Tourists' perceptions of the Canada-USA border as a barrier to tourism at the International Peace Garden. Tourism Management 24(4): pp. 411-421. DOI: https://doi.org/10.1016/S0261-5177(02)00113-9 
TIMOTHY, D. (2005): Shopping Tourism, Retailing and Leisure. Channnel View Publications, Clevedon.

TIMOTHY, D. J. (1997): Selling to tourists: Indonesian street vendors. Annals of Tourism research 24(2): pp. 322-340. DOI: https://doi.org/10.1016/S0160-7383(97)80004-7

TOMONORI, S. - KAZUTO, I. - OSAMU, I. - MIKA, M. (1994): A model for predicting the temporal distribution of one-day recreational travel. Transportation Planning and Technology 18(3): pp. 199-221. DOI: https://doi.org/10.1080/03081069408717544

TÓTH, G. - KINCSES, Á. - MICHALKÓ, G. - TÖMÖRI, M. (2017): Characteristics of transit tourism in Hungary with a focus on expenditure. Regional Statistics 6(2): pp. 129-148. DOI: 10.15196/RS06207

UNODC (2020): World Drug Report. United Nations publication, Sales No. E.20.XI.6.

VON LAMPE, K. (2011): The Illegal Cigarette Trade. In: Natarajan, M. (ed.): International Criminal Justice. Cambridge University Press, New York. pp. 148-154. DOI: https://doi.org/10.1017/9781108597296.008

VON LAMPE, K. - KURTI, M. - BAE, J. (2014): Land of opportunities: the illicit trade in cigarettes in the United States. In: van Duyne, P. - Harvey, J. - Antonopoulos, G. -Maljevic, A. - Markovska, A. - Von Lampe, K. (eds.): Corruption, Greed and Crime-Money: Sleaze and Shady Economy in Europe and Beyond. Wolf Legal Publishers, Oisterwijk. pp. 267-289.

WEISS, T. (2015): The United Nations: before, during and after 1945. International Affairs 91(6): pp. 1221-1235. https://doi.org/10.1111/1468-2346.12450

WESSELY, A. (2000): Utazó emberek, utazó tárgyak. Replika 39: pp. 95-106.

WILLIAMS, A. M. - BALÁŽ, V. (2002): International petty trading: Changing practices in trans-Carpathian Ukraine. International Journal of Urban and Regional Research 26(2): pp. 323-342. DOI:10.1111/1468-2427.00382

WILLIAMS, A. M. - BALÁŽ, V. (2005): Winning, then losing, the battle with globalization: Vietnamese petty traders in Slovakia. International Journal of Urban and Regional Research 29(3): pp. 533-549. DOI: https://doi.org/10.1111/j.1468-2427.2005.00604.x

XHENETI, M. - SMALLBONE, D. - WELTER, F. (2013): EU enlargement effects on crossborder informal entrepreneurial activities. European Urban and Regional Studies 20(3): pp. 314-328. DOI: https://doi.org/10.1177/0969776411434849

YALÇIN-HECKMANN, L. - AIVAZISHVILI, N. (2012): Scales of trade, informal economy and citizenship at Georgian-Azerbaijani borderlands. In: Bruns, B. - Miggelbrink, J. (eds.): Subverting Borders. VS Verlag für Sozialwissenschaften,Wiesbaden. pp. 193-211.

ZÁTORI, A. - MICHALKÓ, G. - T. NAGY, J. - KULCSÁR, N. - BALIZS, D. (2019): The tourist experience of domestic VFR travellers: the case of Hungary. Current Issues in Tourism 22(12): pp. 1437-1459. DOI: https://doi.org/10.1080/13683500.2017.1371117 